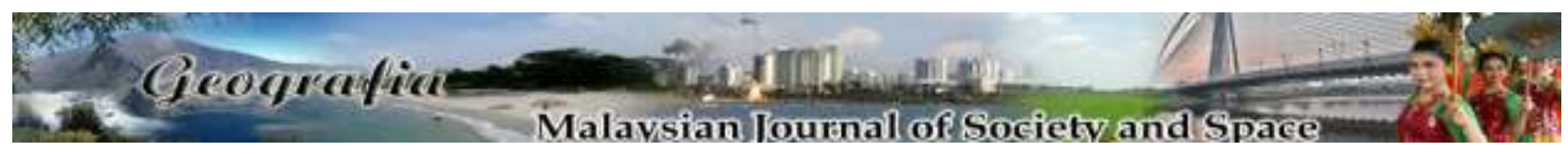

\title{
Combating homelessness: Insights from a homeless population
}

\author{
Syazwani Drani, Azlinda Azman, Paramjit Singh Jamir Singh \\ Social Work Department, School of Social Sciences, Universiti Sains Malaysia \\ Correspondence: Azlinda Azman (E-mail: azlindaa@usm.my)
}

Received: 18 August 2019; Accepted: 29 June 2020; Published: 28 August 2020

\begin{abstract}
There are adequate discussions in literatures to define and discuss homelessness and the homeless. One definition of a homeless is an individual who does not have a permanent dwelling, but live on the streets or at shelters as temporary arrangements. Homelessness is due to several factors, which is also adequately discussed in the literatures. Being homeless, usually gives a negative perception on the wellbeing and social functionality of the homeless individual. This study aims to understand the pertinent issues from the perspective of the homeless. Primary data for this qualitative study were gathered through in-depth interviews of 20 homeless respondents in Penang. The study findings indicate that the underlying causes of homelessness are varied with the main ones being financial and family problems; and alcohol and drug related. Addressing these underlying causes is best way to address the homelessness problem in a more sustainable manner. Some strategies to reduce the number of homeless population based on the study include to better coordinate distribution of free food to reduce overdependence by the homeless, free housing if the case merits it and finally the need for more professional or qualified social workers who can work more closely with the population to empower them to lead a normal life and be less dependent on free handouts.
\end{abstract}

Keywords: homelessness, strategies, social support services

\section{Introduction}

Homelessness is a universal problem. Rich and poor countries have homeless population. Predictably, there are more homeless population in poor countries than the richer countries. The reasons for being homeless thus vary. Many are homeless due to unfortunate circumstances and others become homeless simply by choice. Homelessness is a fascinating phenomenon that warrants better understanding of the problem and its underlying issues. While the homeless do not usually cause a direct problem to society, their existence is perceived as a social misdemeanour that needs to be addressed effectively. Malaysia is no exception as it has a small homeless population, relative to the current 30 million total population and has the attention of 
government agencies and non-governmental organisations to assist, alleviate or lend support to address the issues of homelessness.

Table 1 shows the statistics on the number of homeless population from 2011 to 2015 provided by the Department of Social Welfare Malaysia. While it is quite encouraging that the population is relatively small, it has increased almost 10 percent over the period 2011-2015. The number of homeless dropped temporarily in 2012 and 2013. This merits an explanation to the fluctuation in the numbers, although this is not the intention of this study to identify the reasons. Malaysia do have its share of homeless population and consequently the need to better understand the plight of the homeless population.

Table 1 Statistics of homeless people from 2011 to 2015

\begin{tabular}{ll}
\hline Year & Total of homeless people \\
\hline 2011 & 1,408 \\
2012 & 1,223 \\
2013 & 1,048 \\
2014 & 1,469 \\
2015 & 1,527 \\
\hline Source: Department of Social Welfare, Malaysia (2015).
\end{tabular}

Homeless people often faced various problems, especially on safety, food and shelter. They encounter many social disadvantages which prevent them from being able to fit into the society. According to Ghee and Raja (2015), homeless people tend to have limited access to private and public services such as education, employment, banking services and healthcare. Homeless people are also associated with poor medical conditions. Ahmad Yani, Zahari, Abu Samah, Mohamed Azahar, Yasin, Ahmad Saman and Mohd Noor (2016) found that injuries, for example motor vehicle accident, diabetes mellitus, asthma, cough, itchiness, headache and migraine were the medical conditions that are often faced by the homeless people.

Previous studies showed that there is no one clear definition of the homeless. However, some researchers interpreted homeless from both the statutory context and the voluntary organization perspectives. From the statutory context, homeless can be defined as individual or family that does not have a residence and who choose to live anywhere he or she feels comfortable. Voluntary organizations that provide direct services to this population, characterized a homeless as an individual that faces various problems and generally receives sympathy from the public (Ravenhill, 2014). A homeless normally moves from one place to another. Often society regards the homeless as individuals who lose functionality in a family or community.

According to Forchuk et al., (2011), homeless individuals are triggered by the faintness of the socioeconomic system that does not favor them. While Gaetz, Donaldson, Richter and Gulliver (2013) stated that the occurrence of homelessness is due to poor social relation interactions, loss of residence, a disappearance of social relationships and dysfunctional financial resources. Crane and Warners (2001) observed that homelessness is a result of many factors including expulsion from families, loss of spouse caused by death or divorce, retirement and thus loss of income and age factor. Homeless individuals are often considered as weak and not resilient enough to fulfill their daily needs (Housing and Urban Development, 2009). Deemed as helpless, they are seen as a nuisance or a source of affliction and are also prone to physical or verbal abuses. Their vulnerabilities often lead to multiple issues involving health, violence and violation concerning their property and dignity (HUD, 2009). 
According to Mansor (2017), there are several factors that cause homelessness, which include poverty, drug and alcohol addiction, negative family relationship, age factor and financial and mental health problems. Homelessness is also a result of individuals being victims of crime and sexual violence (National Coalition for the Homeless, 2008). Thus, those who are going through a homeless life live under pressures and frequently face obstacles in their daily routine that may lead to disruption of their whole life.

Beamer, Corole, Hodges and Ella (2014) suggested that there is a need to conduct a study in order to understand better the life and needs of the homeless. With better understanding of the homeless' needs, it is possible to provide a more effective and relevant services that can remotivate this group of population to return to a more normal life. Kryda and Compton (2009) asserted that every service offered should be aligned with the needs of the homeless themselves. On the contrary, many services provided by the relevant agencies were often ignored by the homeless, since the services did not meet their needs. There is a need for social workers to play an important role in bridging this gap in order to ensure that existing services for the homeless are coordinated according to their needs (Kryda \& Compton, 2009).

According to Jost, Levitt and Porcu (2011), the homeless do require support services provided by the relevant agencies. Nevertheless, their lack of knowledge to call for assistance, negligence of their rights for support, social workers' insensibility and bureaucracy issues has somewhat resulted in rejection of the services offered. Williams and Stickley (2011) emphasized that the needs of the homeless will only be known when they are given some space to express their needs or in other words when their needs are being heard. Such action is deemed important in order to ensure more efficient and meaningful intervention by the relevant authorities or stakeholders. Hence, there is a justification to explore and discover the problems and needs of this group of population in greater depth.

This study aims to: (i) analyse the needs of the homeless; (ii) analyse the relevance of the current program for the homeless; (iii) propose appropriate social work intervention strategies in order to help improve the social functioning and wellbeing of the homeless.

\section{Method}

\section{Research Design and Sample}

This study employs the qualitative research design with the aim to identify the needs of the homeless and appropriate intervention strategies to improve the wellbeing of the homeless population. A total of 20 respondents were selected for interview based on their status as a homeless. In this study, purposive sampling was chosen in order to obtain the respondents. Of the 20 respondents, 10 respondents were from those who live on the streets, while the remaining 10 respondents were those who live in a one-stop center that provides social support services to assist any target groups that require the needed social services. All of the respondents resided in the state of Penang, Malaysia. Respondent were selected based on the following criteria: (i) Homeless without a permanent home; (ii) Gender; (iii) Religion; and (iv) Sanity. This criteria were chosen to enable the researcher to obtain in-depth and holistic information based on established objectives. 


\section{Data Collection}

This study employed a semi-structured interview using an in-depth interview technique. Questions directed to the respondents during the interview in order to obtain responses in relation to research objectives. Additionally, each question was broken down to several predefined categories. Each interview took approximately 45 minutes up to an hour. The interviews were conducted at the respondent's homeless location with their full consent. All interviews were audio-taped with respondents' consent as face to face interview alone cannot capture all the dialogue and nuances of the conversations. In addition, the audio-taped interviews were to ensure the reliability and validity of the gathered data.

\section{Data Analysis}

Each of the interviews in this study was carefully transcribed and analyzed several times in order to ensure the accuracy of the data. The transcribed data was manually analyzed using content analysis technique. The transcribed data was then grouped into different themes in accordance with the themes and sub-themes which were in line with the objective of this study.

\section{Ethical Considerations}

Before the interviews began, each of the respondents was briefed on the objective and scope of the study. The respondents were informed about their rights to withdraw from the study at any time without any penalty. Respondents were then asked to state their written informed consent upon agreement to participate in the study.

\section{Study Findings}

Based on the research findings, the study was able to provide some suggestions that can help to improve the homeless living conditions in a more holistic manner. Responses from the population themselves able to provide better understanding on the development of a more comprehensive programme. The study findings are presented in the following detail.

\section{Respondents' Profile}

Table 2 shows details of the respondents' age, gender, marital status and race. There were two respondents each in the 20-29 and 30-39 year-old age group and five each in the 40-49, 50-59 and 60-69 year-old age group. Only one respondent is in the 70-79 year-old age group, who was a married 75-year-old Chinese man. The youngest respondent was a 20 -year-old single Malay man.

Of the total respondents, 17 were males and three females. Twelve (12) claimed to be single, five (5) are still married and the remaining three (3) were divorcees. Several of the respondents were already separated from their spouses prior or after they became homeless. Majority of the respondents were Malays (12), while the rest were equal number of Chinese (4) and Indians (4). All respondents provided full cooperation during the interview sessions. 
GEOGRAFIA Online ${ }^{\mathrm{TM}}$ Malaysian Journal of Society and Space 16 issue 3 (83-93)

(C) 2020, e-ISSN 2682-7727 https://doi.org/10.17576/geo-2020-1603-07

Table 2. Respondents' Profile (age, sex, marriage status and race)

\begin{tabular}{cccll}
\hline Respondent & \multicolumn{3}{l}{ Characteristic } & \\
\cline { 2 - 5 } Total: 20 individuals & Age (Year) & Sex status & Marital & Race \\
\hline R1 & 60 & Female & Married & Indian \\
R2 & 46 & Male & Single & Indian \\
R3 & 65 & Male & Married & Malay \\
R4 & 38 & Male & Single & Indian \\
R5 & 58 & Male & Divorcee & Malay \\
R6 & 75 & Male & Married & Chinese \\
R7 & 61 & Male & Single & Chinese \\
R8 & 20 & Male & Single & Malay \\
R9 & 24 & Male & Single & Malay \\
R10 & 48 & Male & Single & Malay \\
R11 & 49 & Male & Single & Malay \\
R12 & 45 & Male & Single & Malay \\
R13 & 65 & Male & Single & Malay \\
R14 & 53 & Male & Single & Chinese \\
R15 & 59 & Male & Married & Indian \\
R16 & 64 & Male & Single & Malay \\
R17 & 55 & Female & Married & Chinese \\
R18 & 35 & Female & Divorcee & Malay \\
R19 & 54 & Male & Divorcee & Malay \\
R20 & 41 & Male & Single & Malay \\
\hline
\end{tabular}

\section{Causes of Homeless}

Result of the study shows that there are four main (4) causes that contributed to the respondents being homeless. These include financial issues, family conflicts, drug and alcohol abuse or addiction and sense of comfort after choosing to become homeless.

\section{Financial Issues}

Most of the respondents claimed that they had suffered from financial problems. Increased living cost and economic recession made it harder for them to sustain their living coupled with low salary to make ends meet. Hence, the choice to lead a life of a homeless.

\section{Family Conflict}

This study also discovered that family conflicts are another reason for a person to choose a homeless life. They left homes after family disputes or arguments and become homeless when they could not afford to rent a proper dwelling.

\section{Drug and Alcohol Abuse}

In addition, the homeless respondents in this are drug users, ex-drug users or alcoholics, who were castoff by their families. With loss of social support, they felt useless and hence the choice to become homeless. 
Sense of Comfort

This study also ascertained that the sense of comfort is causing the homeless to stay homeless. Such sense of comfort is due to their lack of commitments. Most of them believed that being homeless is better since food is easily available from many charitable individuals and organisations. The availability of food kitchens or free food prepared and distributed by several volunteer agencies has caused the homeless population towards a dependency attitude. It was clearly indicated by the homeless that they were not worried about food because they have easy and regular access to free food that are available almost every day. This is evidenced by the results of interviews with respondents. Almost all of the respondents feel comfortable with life as their daily food needs are met. The following are examples of interview verbatim with regards to free food availabilities.

\section{Respondent 2}

Saya selesa dengan keadaan saya sekarang. Ada duit saya akan makan. Tak ada duit tak apa, saya akan duduk di sini. Pasti akan ada orang yang akan beri duit atau menghantar makanan kepada saya.

(I am comfortable with my situation now. If there is money, then I will eat. If not, I'll just sit here. There will certainly people who will give out money or deliver food to me).

\section{Respondent 3}

Saya tidak mengganggu sesiapa. Orang ramai juga tidak memperdulikan saya. Sekurang-kurangnya saya ada makanan. Hal lain saya tidak peduli.

(I don't bother anyone. People also don't bother me. At least I have food to eat. I don't care of anything else.)

\section{Respondent 6}

Jika saya mahu sewa rumah agak mahal. Begitu juga dengan sewa bilik. Kadar sewa juga mahal. Duduk di sini seperti sekarang lebih senang. Sewa pun tidak perlu bayar.

(If I want to rent a home, it's quite expensive. Similarly renting a room. Rental rates are high. Sitting here like now is easier. No need to pay rent.)

\section{Respondent 19}

Pakcik tidak rasa susah. Tentang makanan untuk pakcik tidak menjadi masalah. Sekitar sini ada tempat yang menyediakan makan tiga (3) kali sehari. Kalau pakcik ada duit pakcik beli makan sendiri. Adakalanya ada orang hantar makanan. Setakat nak rehat dan tidur, cuma perlu lapik kotak dan selimut. Tak perlu fikir perkara lain.

(I don't feel destitute. Food for me is not a problem. Around here there are places that provide food three (3) times a day. If I have some money I will buy my own food. Sometimes there are people who sent me food. So if I want to rest and sleep, I just need a box to sleep on and a blanket. No need to think of other things). 


\section{Future Hopes / Needs}

The study findings have indicated that most of the respondents become homeless for many reasons and living on the streets is their only choice although unconducive. The respondents have also indicated the need for a proper living arrangement as they do not have any financial support to even rent a home or a room and being homeless is the best option for the moment. This is clearly indicated by few respondents as follows:

\section{Respondent 1}

Kalau kerajaan boleh bagi rumah untuk saya tidur, duit sikit, cukup la. Lain-lain saya tak mahu.

(If the government can provide me house for me to sleep, a little bit of money. I don't need other things)

\section{Respondent 3}

Saya nak duit dan rumah. Itu sahaja.

(I just need a house and money. That's all)

\section{Respondent 6}

Saya mahu tempat tidur saja. Rumah ka apa.. tapi sewa tak boleh la. Duit tak banyak. Mahu makan lagi. Ada rumah itu tempat elok sikit untuk tidur, boleh rehat, mandi semua sudah cukup. Siang pi kerja malam saja tidur.

(I just want a place to sleep. Such as a house. But I can't afford to pay rent. I don't have enough money. I need the money for food. I just need a proper house to sleep, rest and shower. Day time I will go to work and I will come back to sleep at night)

\section{Respondent 11}

Saya kalau boleh nak minta rumah PPR dan bantuan bulanan yang selalu orang dapat RM300. Yang tu saja lain-lain tak dak apa..

(If possible, I want to ask for a PPRT house and monthly financial aid RM300. That's all I need. I don't need other things)

\section{Discussion}

The NGOs that provide food and other welfare services include the Light House, Islamic Charity Society and UNGGAS, while Anjung Singgah represents a government organization. It has been observed by the researchers that at times non-homeless civilians and tourists also took advantage of the free meals provided by these organisations.

Since obtaining sustenance such as food is quite easy, it appears as though a homeless life could not be as difficult as it is portrayed. This has caught researcher's attention because the homeless actually do not have to worry about getting food, which were often provided for free by the many agencies and voluntary organizations. The results of this study are similar to those conducted by McGhee (2014) who found that every time food preparation was done in the 
shelter, he later found that there was an increase in the number of individuals present that day compared to the day before queueing up for free meals.

It is the primary purpose for these relevant agencies to help the homeless cope with their daily living, particularly in having adequate food or sustenance. Adversely, the overly concern by these agencies have indirectly created dependency attitude, and feeling of complacent among the homeless population. This is obvious as respondents themselves have reported that they usually have access to substantial amount of food. This also coincides with the report written by a Malaysian newspaper, Date Line (2019) in which they reports that they received a large amount of food. All are provided by individuals and non-governmental organizations.

Based on the current dynamics in helping the homeless, obviously there is a great need to reexamine the existing free food services organized by both the government and the nongovernmental agencies. For example, there are agencies that provide food three times a day on every day. Other agencies provide free food once a week. This study strongly suggests that the government or NGOs that provide food on a daily basis should reduce it to once a week. While those that provide weekly meals may reduce it to once a month. There should be coordination between these agencies. Nadia (2019) states that homeless people receive food donations provided by the agency three times a day with large and varied amounts of food. Amiruddin Abdul Rahman (2017) states that the Malaysian government has directed non-governmental organizations to feed the homeless. This is to ensure that there is no food wastage and activities that contributes to public littering. In fact, agencies are also asked to make regular and more systematic donations of food.

In order to improve the quality of life of this group of population, the study suggests that as a priority the government can provide the homeless affordable housing similar to the current "Projek Perumahan Rakyat Termiskin (PPRT)" or Housing Project for the Absolute Poor. The provision for example can be in a form of a reward for the homeless who have demonstrated to successfully change their lives. Such intervention however needs to be wisely implemented so that the homeless do not take advantage of the subsidized housing or free housing schemes. The homeless must show commitment so as to ensure sustainability of the scheme (Drani, 2016).

Shinn, Weitzman, Stojanovic, Knickman, Jimenez, Duchon, James and Krantz (1998) also proposed similar strategy. A subsidized housing for the motivated homeless to enable them have a better life and to end homelessness. According to Stephenson (2006), such provision of protection can also prevent illness to the homeless. It is crucial that the government and related NGOs should work together. Besides detailed planning of the scheme, identifying the right homeless to benefit from the project is crucial to ensure success and sustainability of the project. Affordable housing can motivate the homeless population to remain in a more healthy and positive living environment.

\section{Recommendation and Conclusion}

Homelessness in Malaysia is under the Destitute Persons Act 1977. To date, there is no specific policy to protect homeless. The Ministry of Women, Family and Community Development, Malaysia is currently proposing amendments to the Destitute Persons Act 1977 by inserting elements of enforcement in the Act. This objective of this amendment is to eradicate the activities of beggars. This is another effort to avoid social dysfunction among the homeless from ending up as beggars. 
This study has clearly identified that the homeless have great difficulty in meeting their financial needs. It is prudent to critically review the shortcomings of the current financial assistance services available to this group. Improvements must be made to ensure the welfare services to the target groups is met in order to help them be out of the poverty cycle. The relevant government agencies and NGOs must continue to work closely in order to provide the best support services to this group of population. For example the two very related agencies under the Ministry of Women, Family and Community Development, the National Welfare Foundation and the Department of Social Welfare, must continue to work closely in providing the best services for the homeless. The introduction of "Anjung Singgah", a that provide services to the homeless is a step in the right direction in bringing the desired differences in the lives of the homeless.

The roles and involvement of professional social workers need to be strengthen as they have the abilities and expertise in handling various social problems, including issues faced by the homeless population. Social workers were trained and geared specifically to work with individuals and groups in need. This study found that most of the social workers in the government agencies and NGOs, including those who deal with the homeless population, do not have the professional social work background. Such officers, who claim or were appointed as a social worker, may have the lack adequate understanding on homeless problems. A social worker is trained to handle such problems professionally. It is the responsibility of every government agency or NGOs to recruit trained social workers to handle homelessness in a more professional manner.

Approaching the homeless requires specially trained communication, listening and observation skills in order to obtain the correct information from them. Otherwise, they prefer to remain silent and live alone, shutting themselves out from the public. Help and support are greatly needed from all the parties to get them break out this vicious cycle. The social work profession are trained to mitigate these problems and to fight inequalities and injustices that existed in social life.

The International Federation of Social Workers (IFSW) and the International Association of Schools of Social Work (IASSW, 2004) states that the profession of social work is one of the changing agents in the social system in a problem solving that involves a human relationship. Social workers can play their role in providing services for the homeless to rebuild their ability to change their life. Social workers are equipped adequately with knowledge, values, ethics, skills and scientific knowledge on human behaviour with specific focus on social justice and equality so that they can serve and fulfil the needs of individuals, families and communities and even countries. Social workers have the skill to empower their clients towards improving their wellbeing in a given society.

As a conclusion, the approach highlighted earlier is hoped to become one of the element for comprehensive restructuring which will empower the homeless population. Based on the problems faced and needs required by the homeless, the establishment and reinforcement of auxiliary support services should be revised from time to time, so that the services provided will always fit to the current needs and situation. Hence, this will help to ensure and maximize the homeless survivability holistically. It is also Malaysia's wish to reduce, if not eradicate homelessness in the country. 
GEOGRAFIA Online ${ }^{\mathrm{TM}}$ Malaysian Journal of Society and Space 16 issue 3 (83-93)

(C) 2020, e-ISSN 2682-7727 https://doi.org/10.17576/geo-2020-1603-07

\section{Reference}

Ahmad Yani, Nurul Mahfuzah and Zahari, Nur Zakirah and Abu Samah, Nur Fatini Haziqah, Mohamed Azahar, Muhammad Ammar Faidhi and Yasin, Siti Munira and Ahmad Saman, Mohd Shahril and Mohd Noor, Nor Aini (2016). Factors associated with homelessness and its medical issues among urban Malaysians: a qualitative research. Journal of Clinical and Health Sciences, 1(1). pp. 46-58. ISSN 01827-984X.

Amirudin Abdul Rahman (2017). Daftar dengan DBKL dulu sebelum bantu gelandangan, NGO diberitahu. Retrieved from https://www.freemalaysiatoday.com/category/bahasa/2017/ 06/23/daftar-dengan-dbkldulu-sebelum-bantu-gelandangan-ngo-diberitahu/

Auckland City Mission. (2006). Auckland City Mission: Annual Report 2006. Auckland, New Zealand.

Beamer, Patricia, C. M., Hodges, \& Sharon, E. M. (2014). "Chronically Homeless: Service Needs" Electronic Theses, Projects, and Dissertations. Paper 98.

Crane, M., \& Warnes, A. M. (2001). Primary health care services for single people: Defects and opportunities. Family Practice-An International Journal, 18(3),272-276.

Department of Social Welfare Malaysia. (2015). Retrieved frorm: http://www.jkm.gov.my/jkm/ uploads/files/penerbitan/Buku\%20JKM\%202015\%E2\%80\%A2Final.pdf

Forchuk, C., Scholfield, R., Joplin, L., Csiernik, R., Gorlick, C., \& Turner, K. (2011). Housing, income support, and mental health: Points of disconnection. In C., Gaetz, S. A., Donaldson, J., Richter, T., \& Gulliver, T. (2013). The state of homelessness in Canada 2013: Toronto: Canadian Homelessness Research Network Press. Retrieved from http://www.homelesshub.ca

Ghee, W. Y and Raja, O. R. N. (2015). Homelessness in Malaysia: victims of circumstance or by choice?. Asian Journal For Poverty Study.

Housing and Urban Development. (HUD, 2009). Continuum of Care 101. Retrieved from: https://www.onecpd.info/resources/documents/CoC101.pdf.

International Association of School of Social Work (IASSW). (2004). Definition of social work. Retrieved from www.ifsw.org/pulication/4.6e.pub.htm.

Jost, J. J., Levitt, A. J., \& Porcu, L. (2011). Street to home: The experiences of long-term unsheltered homeless individuals in an outreach and housing placement program. Qualitative Social Work, 10(2), 244-263.

Kryda, A. D., \& Compton, M. T. (2009). Mistrust of outreach workers and lack of confidence in available services among individuals who are chronically street homeless. Community Mental Health Journal, 45,144-150.

Mansor, N. (2017). Gelandangan: Di mana penyelesaiannya? Retrieved from http://www. utusan.com.my/berita/nasional/gelandangan-di-mana-penyelesaiannya 1.497319.

Nadia Ismail. (2019). Tinjauan: Banyak lebihan makanan terbuang. Retrieved from: https://malaysiadateline.com/tinjauan-banyak-pilihan-punca-makanan-terbuang/

National Coalition for the Homeless. (2008). Hate, violence, and death on main street USA: A report onhate crimes and violence again people experiencing homelessness 2007. Washington, DC. Retrieved from http://www.nlchp.org/content/pubs/Hate_Violence _And_Death_on_Mai_Street_USA_20073.pdf

Ravenhill, H. M. (2014). The culture of homelessness: An ethnographic study. UMI Disertation Publishing. Retrieved from http://etheses.lse.ac.uk/2665/1/U615614.pdf 
Shinn, M., Weitzman, B. C., Stojanovic, D., Knickman, J. R., Jimenez, L., Duchon, L., James, S., \& Krantz, D.H. (1998). Predictors of homelessness among families in New York City: from shelter request to housing stability. Am. J. Public Health 88:1651-1657.

Stephenson, S. (2006). Crossing the Line: Vagrancy, Homelessness and social displacement in Russia, Ashgate, Aldershot.

Syazwani, D. (2016). Dinamik kehidupan golongan gelandangan di Pulau Pinang. (Unpublished PhD Thesis). Universiti Sains Malaysia, Pulau Pinang, Malaysia.

Williams \& Stickley, T. (2011). Stories from the streets: people's experiences of homelessness. Journal of Psychiatric and Mental Health Nursing. 18(5), 432-439. 